\title{
Poetika Osvobozeného v opavském výkřiku
}

\author{
Andrea Jochmanová
}

Jiří Knapík. Heller E̋ Kristian aneb Opavská Vest pocket revue (1933). Hra „Kaolin a Majolika“ a inspirace Osvobozeným divadlem. Edice pramenů. Opava: Filozoficko-přírodovědecká fakulta v Opavě, 2020. 215 s.

Čas od času se v naší divadelně-historické disciplíně máme možnost setkat s ojedinělým výzkumem vycházejícím z okruhů, jež by se mohly na venek jevit jako silně vyčerpané, dokonce přebrané. Také slavná „ohlodaná kost“ české avantgardy přináší, i přes mírně fatalistické prognózy o nulových možnostech posunout výzkum ještě dál, čas od času velmi syté výsledky bádání těch, kteří se nenechají odradit a soustavně hledají odpovědi na svoje otázky. Výzkumem, který vzešel doslova z mála, za nímž stojí několik let získávání materiálů, jejich zkoumání a doplňování, se zabýval Jiří Knapík z opavské univerzity. Nejen, že se výsledkem jeho úsilí stala velmi sympatická monografie zajímavého formátu a př́jemného grafického zpracování, zároveň se autor velmi účinně vyrovnal i s nutností odhalit mnoho souvislostí, jež se k celému avantgardnímu projektu vztahují. Jak už plyne z názvu publikace, nabízí autor možnost nahlédnout do sféry divadla, jehož přesah vedl ke vzniku hned několika výrazných lokálních fenoménů inspirovaných Osvobozeným divadlem, resp. tvorbou Jiř́ího Voskovce a Jana Wericha. Připomeňme jen, že v Brně jen několik let před vznikem opavské inscenace Kaolin a Majolika po vzoru Osvobozených, a přesto velmi originálně úřadovala Akademická scéna (1929-1931), ${ }^{1}$ na jiných místech a v ji-

1 Více o tomto sdružení viz (POSPĚCHOVÁ 2000: 93-114). ných souborech naprríč spektrem od profesionálních přes ochotnické, stejně jako loutkářské, se jisté reminiscence dají v době přelomu dvacátých a třicátých let zjevně vystopovat i po mnoha letech, a to i v případech, kdy se jednalo o událost ojedinělou.

Knapíkova kniha zaujme už svou strukturou, stejně jako osvěžujícím stylem vyprávění doplňovaného souvislostmi pracujícími s mnoha faktory, pochopitelně s vynikající znalostí prostředí, osobností, místopisu, typologie domácího koloritu, silné citové pouto $\mathrm{k}$ vlastním kořenům a dalších důležitých společensko-kulturních vlivů. Jakkoliv zůstala inscenace Kaolin a Majolika v podstatě jednorázovou událostí, po níž za pár let nezůstaly žádné významnější reflexe, s proměnou a jiným zacílením doby postupně ztrácející nejen svou tvář, ale pozvolna i stopy v historii města, povedlo se autorovi při jeho velmi pečlivém přístupu k bádání a snad i díky náhodám, co náhody většinou vůbec nejsou, vyhledat a oslovit nejen rodinné př́islušníky těch, kteří se na inscenaci podíleli, hlavně ale díky velmi pečlivému osobnímu přístupu a zjeveně i hnacímu motoru hledačského úsilí, které z výsledného tvaru čiší, objevit takovou škálu souvislostí, že jeho výsledné dílo zrcadlí vzácný soulad erudice, tvưrčího nasazení, kultivované ambice a v neposlední řadě energie.

Kniha, která vyšla jen v omezeném nákladu, svým rozsahem a odborným přesa- 
hem vnáší novou dynamiku i do problematiky výzkumu dějin divadla v české řeči v místě, kde profesionální divadlo provozoval německý soubor a v době, která sama sebe začala pod vlivem nových tendencí svérázně reflektovat. Ostatně autoři osobité revue Kaolin a Majolika nepopírali vliv humoru Voskovce a Wericha, jejich další spoluautoři pracovali pro generačně spřízněný humoristický časopis Trn, zrcadlícím humor mladé umělecké generace, která díky němu získávala prostor pro rozmanité podoby svých osobitých výpovědí o světě. Z dnešního pohledu šlo v podstatě o karnevalové vidění světa, $k$ němuž se ostatně mladá generace hlásila. Už ve dvacátých letech, kdy ještě nebyla vytvořena a důkladně popsána základní koncepce karnevalové kultury, jak o tom píše Bachtin, ${ }^{2}$ se v okruhu generace sdružené kolem časopisu Trn velmi spontánně projevují určité průvodní rysy tohoto druhu vnímání. At̉ šlo o fascinaci všemi možnými žánry a typy lidové mluvy, nadávkami, zapřísaháním se, kletbami užívanými pražskou periferií, ,pepickou' mluvou i žargonem společenské spodiny, což lze dokumentovat právě v příspěvcích do Trnu, nebo se jednalo o blazeovanou zlatou mládež, jejíž řečnický sloh zparodovali naprríklad Voskovec a Werich ve své Vest Pocket Revue v dialogu mezi Áčkem a Bobikem. Co se týče oblasti psaných či slovesných humoristických děl, obraceli se avantgardisté jednak ke klasickým dílům tohoto okruhu, jakými byl Voltairův Candide, Rabelaisův Gargantua a Pantagruel, ${ }^{3}$ Cervantesův Don Quijote, Brandtova Lod' bláznů a samozřejmě také k moderní literatuře, zejména k Haškovu Švejkovi, Ro-

2 Viz jeho studie „Francois Rabelais a lidová smíchová kultura středověku “ (Praha 1975).

3 V Trnu vychází několik ukázek nových překladů tohoto díla. mainsovým Kumpánům, ${ }^{4}$ Jarryho Králi Ubu či Vančurovu Rozmarnému létu.

Celková prvorepubliková politicko-společenská atmosféra pak zřejmě vybízela mladou uměleckou generaci, tedy pouze konkrétní spřízněnou, podobně smýšlející skupinu, k vnímání světa jako jednoho velkého karnevalu, jehož principy umožnily převést deziluzi k nevázanému veselí převrácenému do odlišného řádu univerza, kde je vše jakoby postaveno na hlavu. Přesto má i tento svět z pohledu zmíněné generačně si blízké skupiny své vlastní kontury - je univerzální v tom, že mírí na všechny a na všechno, je všelidový a týká se tedy všech, jde o bachtinovský ,smích světa', a je do třetice ambivalentní. Není tedy jen veselý a radostný, ale i výsměšný, ničivý i obrozující, a samozřejmě míríi i na ty, kdo se smějí, protože i oni vidí ironii svého života v tom, že jsou součástí právě tohoto světa.

Obdobné motivy lze číst i ve scénáři, který je otištěn a čtenářům představen díky autorově úsilí vůbec poprvé. Jak naznačuje autor v úvodních částech knihy, bylo i pátrání po něm událostí vcelku dobrodružnou, stejně jako hledání jakýchkoliv drobností spojených s inscenací, která se uváděla v oblasti Opavy pravděpodobně pouze dvakrát, přičemž krátce po svém provedení postupně vymizela z kulturní paměti města, resp. zůstala zaznamenána jen krátkou zmínkou. Knapíkův výzkum představuje možná $\mathrm{v}$ mírně symbolické rovině to, co je splněným snem každého historika - stejně jako je snem každého amatéra archeologa najít si s detektorem v polích svůj poklad - z krátké zprávy,

4 O dramatizaci tohoto oblíbeného románu se pokusil Miloš Hlávka, na základě jeho úpravy uvádí Frejka svou inscenaci Kumpánů v Moderním studiu (1929). 
která se objevila $\mathrm{v}$ tisku před téměř sto lety sestavil a během krátké doby také publikoval pozoruhodnou zprávu o divadelním úsilí generačně spř́íněných umělců a tvưrců v lokalitě, kde uvedení avantgardního kusu bylo ve třicátých letech zázrakem.

\section{Bibliografie}

POSPĚCHOVÁ, Hana. 2000. Akademická scéna $\mathrm{v}$ zrcadle novinových ohlasů a archivního materiálu. Sbornik praci Filozofické fakulty brněnské univerzity. Q, ̌̌ada teatrologická a filmologická = Otázky divadla a filmu = Theatralia et cinematographica 49 (2000): Q3: s. [93] -114. 